\title{
Experimental Investigation of Formulation and Field Performance of Formate Based Drilling Fluid System for Vertical Well Drilling
}

\author{
Majid Sajjadian $^{* 1}$, Ehsanesmailpor Motlagh ${ }^{2}$, Ali Akbar Daya ${ }^{3}$ \\ ${ }^{1}$ Department of chemistry engineering, Marvdasht Branch, Islamic Azad University Marvdasht, Iran \\ ${ }^{3}$ Department of Mining Engineering, University of Sistan and Baluchestan
}

\begin{abstract}
A formate-based fluid has been successfully used in many HPHT well operations since they introduced in field practice. They have many advantages when compared with conventional HPHT drilling fluids such as: minimal formation damage, maintenance of additive properties at high temperatures, reduced hydraulic flow resistance, low potential for differential sticking, etc. Formate-based fluids can be applied during deep slim hole drilling, shale drilling, and reservoir drilling, salt and gas hydrate formations drilling.

The laboratory research was carried out to determine composition of formate base drilling fluid. It was formulated using sodium and potassiumformate salts, KCL, starch and lime stone. Formate base mud is solid free system. So, mud cake is thin and resilient, it is conductive to improve cementing quality greatly. In the se experiments, formate based drilling fluids containing two types of formate salt (NaF and KF) at different concentrations were tested by a Fan-50 viscometer.
\end{abstract}

Experiments show that the formate drilling system has good rheological property and strong inhibition ability. It shows that potassium formate improves the thermal stability of polymers. Formate based drilling fluid achieve sufficient mud weight around 77 pcf was selected for field trial in one of the exploratory wells. Formate based brineis a free-solid Water Base Mud (WBM) which maintains rheological stability at high temperature and minimizes drilling problems. This case study shows how Formate based mud enhanced the wellbore stability and reduced the testing time and cost. Based on the success fulfield test results, it is planned to drill other deep formation with Formate based fluids in future.

Keywords: Formate-based mud, shale formation, wellbore stability, hole cleaning.

\section{INTRODUCTION}

There are good reasons to improve drilling fluid and management, not least of which is economics. Mud may represent $5 \%$ to $15 \%$ of drilling costs but many cause $100 \%$ of drilling problems. So, petroleum industry drives for improved performance and effectiveness drilling fluid systems.

Formate drilling fluid is a new type of clean brine drilling fluid system which has been developed from inorganic salt brine drilling fluid system. Currently there are mainly three kinds of formate: sodium formate, potassium formate and cesium formate. Compared with conventional drilling fluid, formate drilling fluid is characterized by no bentonite slurry. It is the theoretical foundation that formate drilling fluid can achieve strong inhibitory, and it is also the key to being better than conventional water base drilling fluid. Wang Yongsheng has studied the application effect of the formate drilling fluid in Yingtai gas field in 2012. And this drilling fluid system has helped to protect the reservoir and save the cost. Based on the previous research, this paper is studied for some new findings and applications [1].

Formate brines are revolutionary fluids that can be used to create solids-free drilling and completion fluids with densities of up to $19.2 \mathrm{lb} / \mathrm{gal}$.

Formate brine was first used in 1993 by NAM in the Netherlands as a coiled-tubing drilling fluid in a well sidetracking operation in the Berkel field. At least 400 wells have been drilled and/or completed with formate brines and they have been the subject of more than 30 SPE papers. The remarkable properties of the formate brines make them collectively an "enabling technology" that helps operators deliver wells that are optimized in terms of: 
- Cost

- Productivity

- Lifetime

- Environmental impact

- Liability

The formates are particularly valued as drilling and completion fluids in challenging operational

Environments such as:

- $\mathrm{HT} / \mathrm{HP}$

- Extreme well configurations (ERD,TTD, CTD)

- Sites of ecological sensitivity

The foundations of the formate brine technology in use today were developed principally in Shell Research by the authors of this paper, [2-6] building on an invention filed by Clarke-Sturman and Sturla in 1987[7]. The inventors discovered that the temperature stability of common drilling fluid polymers was increased when they were dissolved in aqueous solutions containing high levels of alkali metal formates. The formates gave Shell the ability to formulate simple water-based drilling and completion fluids for HT/HP well construction operations.

As an added bonus, the almost solids-free drilling fluids prepared from formate brines could reduce ECD, eliminate barite sag problems, and reduce the risk of differential sticking. Shell Research saw that formate-based brines could answer the need for high performance fluids necessary for the implementation of the new drilling and completion techniques that were being introduced in the early1990s. The new techniques were aimed at creating increasingly extreme well configurations and included long horizontal, extended reach, slim hole, through tubing and coiled tubing drilling. These drilling techniques needed solids-free drilling fluids that could minimize circulating pressure losses and ECD. The formate brines provided the ideal basis for such drilling fluids, with the added advantage that they could also function as completion fluids. Further laboratory work over the past 15 years has clearly shown that the formate brines in general havevery good environmental properties, stabilize shales, inhibit hydrate formation, minimize corrosion, reduce well control problems and minimize formation damage. In short, they appear to be the ideal universal drilling and completion fluids that the oil industry needs in the 21st century. [8-9]Shell carried out the first field trial of sodium formate brine in a coiled-tubing drilling job in The Netherlands in 1993. This was followed less than a year later by the first field trial of potassium formate brine in a reservoir drill-in operation in Norway. Since then sodium and potassium formate brines have been successfully used as drilling, completion, packer and gravel packing fluids in at least 400 wells in 15 countries around the world.The final breakthrough in the development of formate brine technology was when cesium formate became commercially available in 1998. In the past 6 years cesium formate brine has been used in $60 \mathrm{HT} / \mathrm{HP}$ drilling and completion operations in the North Sea and the Gulf of Mexico. In recent years the refinement and further development of formate technology has reached a newlevel of intensity, resulting in inventions such as shale stabilization with low concentration formate brines [1012] and formate-based drilling fluids stable up to $400^{\circ} \mathrm{F}$.[13] In addition, formate brines have been passing the most severe corrosion tests.[14-15]

A review of operator's feedbacks from long term use was recently published by Olvik et al. [16]. It underlines the drilling benefits and their operational success. To reduce the negative impact of cost, formate systems can be recovered at the end of each job and recycled [17]. Formate also has the advantage that much of the weight is provided by the base brine resulting in lower solids content [18]. Sodium and potassium formate based drilling fluid have been used in drilling HPHT gas wells in Saudi Arabia since 2004 [19]. Despite many advantages, formate muds are challenged because they might affect standard nuclear logging tools [20].

As hydrocarbons become more difficult and expensive to access, it seems inevitable that the oil Industry will place more emphasis on selecting new technology in drilling fluids that will minimize challenges and optimize drilling rate without the need for further cost. 
The purpose of this research consists of the development of friendly inhibitive which exhibited laboratory performance characteristics which were in the realm of those achieved by invert emulsion fluids, and far exceeded those exhibited by other water-based fluids. This fluid was then taken to the field test stage. The case study presented will document how the formate base drilling fluid has made water-based drilling fluid technical more effective in one of vertical well.

\section{Formate Chemistry}

Formate has the characteristics of high solubility, high density, high $\mathrm{pH}$ value, low crystallization point. With the increase of alkali metal atomic weight, saturation concentration, saturation density and $\mathrm{pH}$ value become higher, and crystallization point becomes lower.

Through indoor study, the following features of for- mate have been found:

1) There is the function of stabilizing shale. Shale is equivalent to the selective semi-permeable membrane in the non fractured low permeability shale formation $\left(\mathrm{K} \leq 10 \times 10-3 \mu \mathrm{m}^{2}\right)$. In the high concentration brine, due to the low water activity, the osmotic pressure can promote the shale pore water reflux. This reflux will make formation stress and effective stress of near wellbore zone increase to stabilize borehole wall.

2) Formate has a good compatibility with the oilfield commonly used polymer, and can slow the speed of hydrolysis and oxidation degradation of many thickeners and filtrate reducers under high temperature and pressure. [21-22]

\section{EXPERIMENTAL SET-UP}

\subsection{Material}

The experimental evaluation consisted of optimizing the Formate Fluids for the well targeting member (A) composed of the shales. The drilling fluid used in this experiment was a water based mud. The chemical composition of the mud is summarized in Table 1.

Table1. Chemical composition of FBM

\begin{tabular}{|l|l|}
\hline Additive & Concentration [PPB] \\
\hline Fresh water & 0.952 \\
\hline Potassium Formate & As needed \\
\hline Soda Ash & 0.85 \\
\hline Starch -Green & 6.82 \\
\hline PAC-LV & 3.4 \\
\hline XC-Polymer & 1 \\
\hline Defomer & 0.1 gal \\
\hline Lime Stone & 9 \\
\hline Sodium bicarbonate & 0.5 \\
\hline KCL & 33.3 \\
\hline Sodium Formate & As needed \\
\hline
\end{tabular}

Besides water, a major contributor to the chemical composition is formate salts. It provides thermal stability and shale inhibitor. Other additives added to improve the drilling fluid are:

$>$ Starch -Green and PAC-LV as polymer to decrease water lost drilling fluid

Lime Stone is necessary as solid particulates for bridging purposes

Caustic Soda to act as $\mathrm{pH}$-modifier

$>$ Glycol and PHPA provide shale stability for water based drilling fluid

Soda Ash to decrease hardness of water.

KCL improves shale inhibition property of drilling fluid.

Sodium and Potassium Formate improve fluid properties under HPHT condition and also, as to serve as a weighing additive.

The material described above is the basic mud unit, or No-salt mud. From this basic mud, another six mud samples were prepared by adding two type of salts, namely, Sodium-formate (NAF) and Potassium formate (KF). Formate mud samples were prepared at two levels of mud weight: $75 \mathrm{pcf}, 78$ pcf. 


\subsection{Instrumentation}

In this research, a laboratory test was carried out to study the effect of formate salt in water base mud (WBM) in preventing shale hydration and dispersion through

Hot rolling dispersion test, based on the American Petroleum Institute - Recommended Practice 13I. The inhibitive features were further evaluated against several shale samples which had different reactivity and clay contents. Besides, the performance of formate based mud was also evaluated through series of rheological properties, fluid loss, mud water activity, and ageing process tests as recommended in the American Petroleum Institute - Recommended Practice - 13B

The test fluids were mixed in stainless steel mixing cups on a five-spindle multi-mixer model 9B with a rotational speed of 11,500 RPM with sine-wave impeller blade No. 9B29X. The fluids were aged in high pressure/high temperature (HPHT) stainless steel ageing cells and hot rolled in a Model 705ES five-roller oven at $250{ }^{\circ} \mathrm{F}$ for 16 hours. The rheology of the fluids was determined at $140{ }^{\circ} \mathrm{F}$ on a 6speed standard oilfield viscometer. The temperature was controlled with an electrically heated thermo cup.[23]

\subsection{Laboratory testing results}

After a few lab trials, and formate fluid properties, Table 2, was selected that met the programmed filtration and rheological properties of the well (Table 3).

Table2. Lab properties of the formate base drilling fluid

\begin{tabular}{|c|c|c|c|}
\hline Mud Properties & Unit & Before Hot roll & Hot roll $16 \mathrm{hr}$ \\
\hline Mud weight & PCF & 78 & \\
\hline Appearance Viscosity & $\mathrm{Cp}$ & 15 & 12 \\
\hline Plastic Viscosity & $\mathrm{CP}$ & 13 & 9 \\
\hline $\mathrm{PH}$ & - & 9.9 & 9.1 \\
\hline Gel & $\mathrm{Lb} / 100 \mathrm{ft}^{2}$ & $1 / 2$ & $1 / 1.5$ \\
\hline Yield Point & $\mathrm{Lb} / 100 \mathrm{ft}^{2}$ & 4 & 6 \\
\hline API fluid loss & $\mathrm{ml}$ & - & 2.5 \\
\hline $\begin{array}{l}\text { HPHT. } \\
\text { FL(500psi/220 } \mathrm{F})\end{array}$ & $\mathrm{ml}$ & - & 4.4 \\
\hline Shale Recovery & $\%$ & $94 \%$ & \\
\hline
\end{tabular}

Table3. Drilling Fluids Properties Programmed and Actual for Drilling Member (A) of the well

\begin{tabular}{|l|l|l|}
\hline Mud properties & Programmed & Actual \\
\hline Mud weight-lb/ft ${ }^{3}$ & $69-78$ & $70-83$ \\
\hline Appearance Viscosity-cp & \pm 40 & $45-50$ \\
\hline Plastic Viscosity-cp & $12-17$ & $15-25$ \\
\hline PH & \pm 9.5 & $9.2-9.9$ \\
\hline Gel $10 \mathrm{sec}, \mathrm{lb} / 100 \mathrm{ft}^{2}$ & $1-3$ & $2-3$ \\
\hline Gel $10 \mathrm{~min}, \mathrm{lb} / 100 \mathrm{ft}^{2}$ & $3-5$ & $3-4$ \\
\hline Yield Point, lb/100ft & \\
\hline API Filtrate, $\mathrm{ml} / 30$ minutes $^{2}$ & \pm 14 & $14-16$ \\
\hline Solis - \% & $<4$ & $2-4$ \\
\hline
\end{tabular}

\section{Field Evaluation}

The vertical well to be drilled was an on well that could provide information on potential reservoirs and litho logical information of the field. No offset data was available on the well and the nearest well information was $80 \mathrm{~km}$ away. Geologist forecast from this well required drilling through reactive shales in member (A). Table 4 lists the interval parameters for drilling.

Table4. Interval well Parameters

\begin{tabular}{|l|l|}
\hline Formation Type & Member A compose of shale \\
\hline Thickness interval depth & 400 feet \\
\hline Interval Hole size & $83 / 8$ inches \\
\hline Fluid Type & Formate based mud \\
\hline Bit type & Mill Tooth bit \\
\hline Nozzle size & $3 * 16 / 32$ inches \\
\hline String Rotation speed(rpm) & $100-130 \mathrm{rpm}$ \\
\hline Weight on Bit (WOB) & $20-25 \mathrm{klb}$ \\
\hline
\end{tabular}


The objective was to drill a 8 3/8-in. hole section from $10900 \mathrm{ft}$ through member (A), to the casing point at a measured depth (MD) of $12500 \mathrm{ft}$. A 7-in. casing string was then to be run and cemented. The FBM optimized for member (A) was expected to provide maximum shale stabilization and inhibition to achieve maximum ROP without any incidents such as tight hole, pipe stuck and hole filling.

The objective was to provide maximum wellbore stability for coring and logging operations without any hole instability or mud problems. The drilling program was executed within the program specifications and within the planned cost and time.

Initially the 7-in. casing cement was drilled, followed by drilling $1000 \mathrm{ft}$ of member (A) formation at MD $10800 \mathrm{ft}$ with the previous section's salt mud.

The salt mud was then displaced with the FBM with a density of 80 pcf per the mud program. After the FBM was circulated and conditioned for 5 hours as bypass. Drilling was performed without any problem with formation loss 1-3 BPH until reaching MD $11270 \mathrm{ft}$, where mud making is no possible because of shortage formate salts. To control this problem, pull out of string $(\mathrm{POOH})$ was done and is decided to change mud formulation system with oil based mud for continuing drill the hole. Drilling time of interval from 10800 to $11270 \mathrm{ft}$ that using Formate based mud was about 70 hours. The use of a formate based drill fluid instead of salt based fluid allowed for beneficial modifications to the drilling practice with positive results:

- It exhibited superior hole-cleaning qualities throughout the interval and no significant drag was observed during drilling. It decreased the need for pills to assist with hole cleaning.

- Flow rates could be increased from typical 350-400 gal/min to $450 \mathrm{gal} / \mathrm{min}$ because of the reduced frictional pressure losses of the formate system.

- It reduced the need for back reaming out of the hole for hole cleaning.

- It achieved faster than expected penetration rates in total formation drilling time was achieved.

After drilling entire the hole, one wire line logging runs were performed over a period of three days, per the planned program, without any problems. Before the logging runs, conditioning trip(wiper trip) were performed, which went smoothly without any tight spots or drag. Because of the perfect open hole stability provided with the FBM, no clean-out trip was performed after the last logging run and before running the casing, thereby saving non-production time consist of tripping time. The 7-in.liner was successfully run to bottom and cementing done per the planned program.

The use of this shale stabilizing fluid has greatly improved drilling performance by reducing trouble time and eliminating drilling problems.

$$
\begin{aligned}
& \text { Nomenclature } \\
& \mathrm{WBM}=\text { Water-based mud } \\
& \mathrm{FBM}=\text { Formate base mud } \\
& \mathrm{ROP}=\text { Rate of penetration } \\
& \mathrm{YP}=\text { Yield point } \mathrm{lb} / 100 \mathrm{ft} 2 \\
& \mathrm{PV}=\text { Plastic viscosity } \mathrm{cP} \\
& \mathrm{Pcf}=\text { pound per cubic feet, } \mathrm{lb} / \mathrm{ft} 3
\end{aligned}
$$

\section{REFERENCES}

[1] Gao, P. and Yin, D. (2006) Simulation study on the conditions of converting injection wells to production wells in low permeability reservoirs. Journal of Daqing Petroleum Institute, 6, 12-22.

[2] Downs, J.D.: "High Temperature Stabilization of Xanthan in Drilling Fluids by the Use of Formate Salts," in Physical Chemistry of Colloids and Interfaces in Oil Production; Editions TechNet, Paris, 1991.

[3] Downs, J.D.: "Formate Brines: New Solutions to Deep Slim-Hole Drilling Fluid Design Problems," SPE 24973, European Petroleum Conference, Cannes, 16-18 November 1992.

[4] Downs, J.D.: "Formate Brines: Novel Drilling and Completion Fluids for Demanding Environments," SPE25177, 1993 SPE International Symposium on Oilfield Chemistry, New Orleans, 2-5 March 1993. 
[5] Howard, S.K.: "Formate Brines for Drilling and Completion: State of the Art," SPE 30498, SPE Annual Technical Conference, Dallas, 22-25 October 1995.

[6] Clarke-Sturman, A.J. and Sturla, P.L.: "Aqueous Polysaccharide Compositions," European patent 259 939(16 March 1988).

[7] Bungert D., Maikranz S. Sundermann, R., Downs,J., Benton, W. and Dick, M.A.: "The Evolution and Applicationof Formate Brines in High Temperature/PressureOperations", SPE 59191, 2000.

[8] Downs, J.D., Killie, S. and Whale, G.F.:"Development of Environmentally Benign FormateBased Drilling andCompletion Fluids," SPE 27143, SPE 2nd International Conference on Health, Safety and Environment in Oil \&Gas Exploration and Production, Jakarta, 25-27 January 1994.

[9] Chenevert, M.E.: "Drilling Fluid Optimization in Shales. Swelling Pressure and Compressive Strength of Shale,Topical Report," Prepared for Gas Research Institute, Contract No. 5093-2102898, December 1998.

[10] Hallman, J.H., Mackey, R., and Swartz, K.: "Enhanced Shale Stabilization With Very Low Concentration Potassium Formate/Polymer Additives," SPE 73731, SPE International Symposium and Exhibition on Formation Damage Control, Lafayette, 20-21 February 2002.

[11] Mackey, R. and Hallman, J.: "Low Concentration Formate Fluids Improve Drilling in WaterBased Muds in DifficultShale Environments in Western Canada," IV SEFLU (Seminarion de Fluidos de Perforacion y Terminacion de

[12] Pozos), Isla de Margarita, Venezuela, 5-8 June 2001. Hallman, J. and Bellinger, C.: "Potassium Formate Improves Shale Stability and Productivity inUnderbalanced Drilling Operations," CADE/CAODC Drilling Conference, Calgary, 20-22 October 2003.

[13] Messler, D., Kippie, D., Broach, M. and Benson, D.: "A Potassium Formate Milling Fluids Breaks the $400^{\circ}$ Fahrenheit Barrier in the Deep Tuscaloosa Coiled Tubing Clean-out," SPE 86503, SPE International Symposium onFormation Damage Control, Lafayette, 18-20 February 2004.

[14] Gao, P. and Towler, B. (2010) Strategies for evaluation of the CO2 miscible flooding process. SPE-138786, Confer- ence of 2010 Abu Dhabi International Petroleum Exhibi- tion, Abu Dhabi, 1-4 November 2010, $10 \mathrm{p}$.

[15] Gao, P., Towler, B. and Jiang, H. (2010) Feasibility inves- tigation of CO2 miscible flooding in south slattery min- nelusa reservoir, Wyoming. SPE-133598, 2010 SPE Wes- tern North American Regional Meeting, 27-29 May 2010, Anaheim, 4-14.

[16] Olsvik G., Howard S., Downs J. (2013) The long-term production performance of deep HPHT gas condensate fields developed using formate brines, SPE Paper 165151, SPEEuropean Formation Damage Conference, Noordwijk, Netherlands, 6-7 June.

[17] Simpson M.A.,Al-Reda S., Foreman D.,Guzman J.,Al-Fawzy M.,Vice P. (2009) Application and recycling of sodium and potassium formate brine drilling fluids for Ghawar field HT gas wells, OTC 19801, Offshore Technology Conference, Houston, Texas, USA, 4-7 May.

[18] Weekse, A., Grant, S., and Urselmann, R. 2002. Expandable Sand Screen: Three New World Records in the Brigantine Field. Paper SPE 74549 presented at the IADC/SPE Drilling Conference, Dallas, Texas, 26-28 February.

[19] Simpson, M.A., AbdRabAlreda, S.H., Al-Khamees, S.A., Zhou, S., Treece, M.D. and Al-Ansari, A.A. 2005. Overbalanced Pre-Khuff Drilling of Horizontal Reservoir Sections with Potassium Formate Brines. Paper SPE 92407 presented at the SPE Middle East Oil \& Gas Show and Conference, Bahrain, 12-15 March.

[20] Moake G.L. (2012) Formate mud effects on density logs, SPWLA 53rd Annual Logging Symposium, Cartagena, Colombia, 16-20 June.

[21] Hands, N., Francis, P., Whittle, A. and Rajasingam, D.: "Optimizing Inflow Performance of a Long Multi-Lateral Offshore Well in Low Permeability, Gas Bearing Sandstone: K14-FB 102 Case Study," SPE 50394, SPE International Conference on Horizontal Well Technology, Calgary, 1-4 November 1998.

[22] McKay, G., Bennett, C.L. and Gilchrist, J.M.: "High Angle OHGP's In Sand/Shale Sequences: A Case History Using a Formate Drill-In Fluid," SPE 58731, SPE International Symposium on Formation

[23] API RP 13I, recommended practice for laboratory testing of drilling fluids, - 6th edition, MAY 2000. 